\title{
Evolution of academic surgery
}

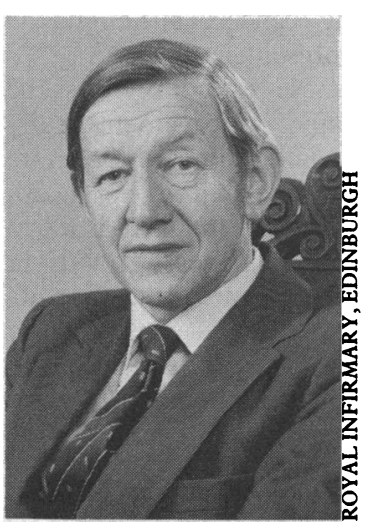

Sir Patrick Forrest

\section{A Patrick M Forrest}

Sitting by the River Dordogne on 14 July, I could not do other than think about the storming of the Bastille, which heralded the start of the French Revolution 200 years ago. Accounts in the English language concentrate on the years of terror rather than on the desperate need for change; for France was, in the words of Dickens, rolling "with exceeding smoothness downhill." Many believe that in Britain clinical academic medicine also is doing just that. Britain abhors violent change, priding itself on evolution not revolution. This may produce the desired effect but only when those to be changed benefit, as in the remarkable social developments during my lifetime. Otherwise the process of evolution carries the risk of the "add on," much of the old, not necessarily the best, being maintained alongside the new, leading to waste, uncertainty, and, at times, chaos. What better example than our refusal to revolve our system of measurement, so that whether buying petrol, food, or planning travel, we are unnecessarily troubling our minds with conversions between litres and gallons, kilograms and pounds, and kilometres and miles. Our European neighbours smile but cannot readily understand.

Those who practise medicine use the most radical of invasive and extirpative procedures yet are fundamentally conservative. Only too often the old is discarded only when those wishing to retain it have ceased to influence events. The process is expensive and in academic circles may cost more than the future permits. Such has been the case in medical education. For example, in surgery specialisation has changed the needs of postgraduate training. General surgery with its subspecialties is now but one of a series of major surgical specialties demanding specialist knowledge and skills. It no longer represents the core knowledge required by all surgeons.

\section{Role of the royal colleges}

The historic role of the royal colleges to license surgeons to practise was endorsed by the Goodenough report, ${ }^{2}$ and in 1975 in a letter to the Lancet a group of us suggested that the royal colleges be required to take note in their examination system, then largely geared to general surgery, of the way in which surgical training had evolved. ${ }^{3}$ This was, firstly, a period of training in the principles of surgery common to all specialties, and, secondly, a period of intensive training in the specialty chosen for future practice. Simplistically, we suggested that fellowship of a royal college should be awarded only after satisfactory assessment that the objectives of these two periods of training had been met and would therefore become, rather than an entrance qualification into specialist training, the hallmark of a British trained surgeon. This view was in line with current thinking in the Edinburgh college, which in 1977 resolved that this was the way forward, and also in the Australasian college, which has since implemented this change. It has recently also been reinforced by our largest surgical association, The Association of Surgeons of Great Britain and Ireland, which at its annual meeting in Edinburgh in March this year agreed on a statement giving its views. ${ }^{4}$ But we were too revolutionary. The process of evolution had to work, with interminable discussions, trials of different forms of accreditation of specialist surgical training, and innumerable reports that only spelt confusion about what our system of surgical training really stood for.

A solution has now been proposed and is being implemented. But again it is but an add on solution. ${ }^{5}$ Fellowship of the royal colleges, modified to assess core knowledge of surgery in general, will continue to indicate only that a young surgeon is fit to enter specialist training, including that in general surgery. An additional examination common to all four colleges will be held during specialist training, which, as it will lead to accreditation in the specialty, will become the main test of a surgeon's competence to practise. The fellowship cannot in any way be regarded as a licence to practise surgery.

Why did we not take the simple, straight and logical road? Regretfully, not on educational grounds but on account of concern for the financial wellbeing and independence of the colleges and for one college outside the United Kingdom the retention of a royal charter. In my view the colleges are neglecting their educational role by not starting afresh and defining in educational terms the requirements of surgical training and how best this can be monitored and assessed. There is need to examine critically the educational requirements not only of young surgeons of British origin but also of those who come from abroad to be trained, who will return to a very different system of health care and surgical practice and for whom didactic courses, cram classes, and inferior hospital posts are but a relic of the apprenticeship and of the private anatomy schools of the eighteenth century. Under the present proposals they will continue to return to their own countries as fellows of a royal college to be regarded as British trained surgeons; which their knowledge, skills, and experience can only deny. I cannot believe that we have got it right, and I believe that academic surgeons have a responsibility to urge that we start again.

\section{Surgical research}

Goodenough emphasised that it was our duty to nurture young research workers, ${ }^{2}$ which in the face of current constraints poses problems. It is common knowledge that our science base is falling. In terms of total expenditure we are now funding less science than France or West Germany. Our world share of published papers and citations has declined. We register fewer patents in the United States and win fewer Nobel prizes; more fellows of the Royal Society now live abroad. Although the situation seems better in biomedical science, in which we are holding our world share of papers, citations are declining, suggesting a loss of quality. But in surgical research we are still on top, and this we must maintain. ${ }^{6-9}$

The main impact we have borne is the collapse of university funding, with a $25 \%$ reduction in clinical academic staff. The expansion in higher education and medical school intake in the 1960s recommended by Robbins ${ }^{10}$ and Todd ${ }^{11}$ was accompanied by a substantial increase in funding from the University Grants Committee. We lived in halcyon days, sitting on top of the solid pillars of the dual support system with our well 
found departments providing the base for the pilot studies that are so necessary for gaining support from the research councils, health departments, and charities. The department in Edinburgh to which I transferred in 1971 boasted no less than eight full time academic staff, 15 technical staff, and eight secretarial staff. But not for long. The volume cuts of the 1970s followed by long term but progressive savings has eroded the university pillar of the dual support system. In a survey which I carried out in 1984 there were on average only 0.8 scientific and $3 \cdot 2$ technical staff in each academic department of surgery, a pathetic base for surgical science.

To this has been added falling grant aid, research councils seeing a less severe but nevertheless steady reduction in their level of funding owing to undercompensation for inflation, less favourable exchange rates for international subscriptions, and the high cost of modern science. In 1984 the numbers of grants averaged six per surgical department, but most came from sources other than the Medical Research Council, which was roundly criticised as being antipathetic to surgical research (table I). It seems, however,

TABLE I-Sources of grants for surgical research, 1984

\begin{tabular}{|c|c|c|}
\hline & \multirow{2}{*}{$\begin{array}{l}\text { General } \\
\text { surgery } \\
(n=30)\end{array}$} & \multirow{2}{*}{$\begin{array}{c}\text { Mean No/departmen } \\
\begin{array}{c}\text { All surgical } \\
\text { departments } \\
(n=47)\end{array}\end{array}$} \\
\hline & & \\
\hline $\begin{array}{l}\text { Medical Research Council } \\
\text { Cancer Research Campaign } \\
\text { Health Department Survey } \\
\text { Wellcome Trust } \\
\text { Others }\end{array}$ & $\begin{array}{l}0 \cdot 5 \\
1 \cdot 1 \\
1 \cdot 0 \\
0 \cdot 6 \\
3 \cdot 4\end{array}$ & $\begin{array}{l}0 \cdot 5 \\
0 \cdot 7 \\
1 \cdot 0 \\
0 \cdot 5 \\
3 \cdot 0\end{array}$ \\
\hline Total & $6 \cdot 6$ & $5 \cdot 7$ \\
\hline
\end{tabular}

that the success rate of grant applications from surgical departments is not disparately low, and we attract a reasonable number of programme grants for long term support (table II). Is it that the type of clinical science we wish to conduct does not appeal and cannot compete with more basic research; that our reputation for self criticism is real and we do not support our own; or that we are just so committed in so many directions that we cannot get our act right?

TABLE II-Medical Research Council grants for surgical research, 1978-83

\begin{tabular}{lcc}
\hline & $\begin{array}{c}\text { No } \\
\text { applied for }\end{array}$ & $\begin{array}{c}\text { No (\%) } \\
\text { approved }\end{array}$ \\
\hline General surgery & 100 & $31(31)$ \\
Orthopaedic surgery & 18 & $4(23)$ \\
Other surgical specialties & 20 & $10(50)$ \\
\hline Total & 138 & $45(32)$ \\
\hline
\end{tabular}

There is also the push towards greater selectivity of research effort. Within universities research committees are to monitor our research performance; universities themselves are being threatened with selective funding, either directly or through research councils; and research councils have to submit corporate plans and, to avoid overlap of interests, are now being faced with submergence into a single large council. Independence is at risk, and as the functions of clinical academic departments are ill understood by so many, surgery may become bottom of the line. The shift in funding of research towards charities and industry also increases selectivity, for they are by definition selective organisations. To these influences we must add the rigidity and service orientation of our training programmes, the lack of career prospects in clinical science, and the internal brain drain offered by the better terms and conditions within the NHS, particularly when reinforced by private practice.

How are we to cope? Firstly, we must concentrate our resources in support of those who are excellent. We can identify them, for the best of our students enter our wards as house surgeons, those interested in surgery seeking soon to return to a junior training post. But they must be nurtured when still young. I am uncertain that we can afford the current trend of regarding a higher academic qualification as a requirement for specialist surgical training. Not only is it an add on element to an already overcrowded and excessively long training programme but also an expensive one. The trainees must be paid, and at clinical rates, and someone must supervise their work and help to write their papers. For most trainees research experience is but a step towards promotion rather than a base for future investigative work: and this is not a good reason.

Secondly, we must ask important questions. As Medawar wrote: "Piffling and unimportant questions yield piffling or unimportant answers." 12 And, as shown from our record of programme grants, important questions get support. In his Harveian oration $^{13}$ Robert Platt decried the importance of research carried out in clinical academic departments of medicine. Research carried out by academic surgeons has led to the control of infection, open heart surgery, coronary artery bypass, hip replacement, the endocrine control of cancer, lithotripsy, and organ transplantation, and such research must therefore be maintained.

Thirdly, we must provide the facilities and the freedom which are needed to satisfy curiosity for knowledge. In 1968, at the time of the Todd report, a university department was an effective unit for research; and laboratory work, supported by scientific staff, was well within the competence of a young surgeon. The situation is changing; only if a department is large, well equipped, and staffed by those conversant with the tools of modern science can we hope to compete. Only a few academic surgeons can have the creativity and scientific knowledge to run a department practising fundamental science. But it is critical to all of us that to maintain our unique position as surgical scientists we apply these same techniques to the solution of clinical problems.

In Duke University top scientists conducting research relevant to surgery work alongside colleagues in preclinical departments, only differing in their

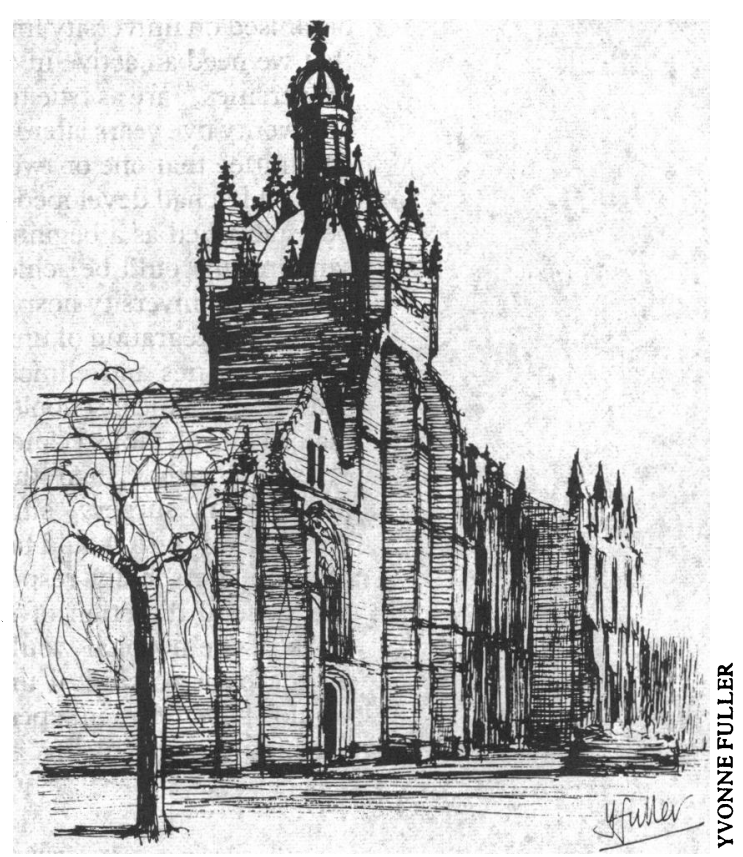

King's College, Aberdeen 


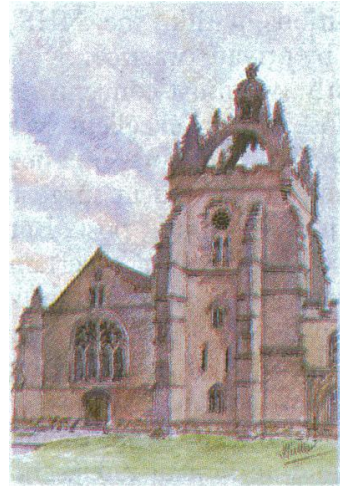

source of income and the clinical nature of their research students. This is not a pattern which has evolved in Britain, but the cooperation which has sprung up in Scotland among academic departments of surgery and the Medical Research Council, Cancer Research Campaign, and Agricultural and Food Research Council research units ensures that young surgeons can learn to use the tools of hard science and later understand its relevance to clinical problems. As Sir Michael Woodruff recently said to me, "one cannot do science by proxy." Such units are not to be found in every university centre-and young surgical research students while still employed by their parent department must be prepared to be mobile, at least during the early stages of their career.

Finally, we must have sound career prospects for the surgical scientist, equal in terms and conditions of service to those of a purely clinical career. The institution by the Medical Research Council of a number of training posts in clinical science at senior registrar level, which is a step in the right direction, does not answer the long term problem, which is to establish within the NHS a cadre of surgical scientists whose role is to advance knowledge in all aspects of health care. I believe that the surgical royal colleges with the health departments should be exploring how this might be achieved, just as in 1930 the Edinburgh college funded two posts to aid development of a modern records system in the royal infirmary to provide a base for clinical research. As the Australasian College of Surgeons, through its research foundation, has established its astonishing record of promoting research in surgery, and as the Royal College of Obstetricians and Gynaecologists has opened the Harris Birthright research unit in this Aberdeen medical centre.

\section{Effecting change}

Flexner advocated that Britain should follow the lead of Germany and establish a model university hospital in which education and scientific endeavour would be fully integrated with clinical practice. ${ }^{14}$ The Haldane commission did not favour this solution but rather advocated the injection of academic units, staffed by full time or almost full time clinical teachers, as had been described by Osler. But Osler, as was clear from his lecture to the Northumberland and Durham Medical Society, was advocating three or four such units each in medicine and in surgery, each one to be organised on university lines. His words: "The truth is that we need an active invasion of the hospitals by the universities," are as true today as in 1910. ${ }^{15}$

Twenty five years later it was put to the Goodenough committee that one or two university hospitals, of the type which had developed in the United States, should be established as a beginning, but it believed that the same result could be achieved by less radical changes and that a university hospital could be created in spirit by closer integration of university and hospital governing authorities and clinical staff, by including in the staff of all medical schools full time professors in each major clinical subject, and by fostering the concept of divisions, rather than that of academic units. The professor of surgery, supported by a few full time members of staff, would be academic head of his or her division, personally responsible for the organisation and general direction of teaching. While the clinical work of the hospital would continue to be conducted on the basis of clinical units the clinicians in charge would have less independence in regard to their teaching duties, being subject to the educational direction of the academic head. But it was fanciful thinking. In the words of the Todd commission, some 20 years later, such coordination and integration as can be achieved "... makes the implementation of a comprehensive educational programme all but impossible." The commission urged that action be taken to ensure that each clinical division of a medical school be brought under the direction of an academic head. Another 20 years have since passed, and, although in some teaching hospitals there have been clear moves towards better integration, the pattern is patchy and dependent upon goodwill and ad hoc arrangements and requires a great deal of time to make it work. In Britain there has been but one university hospital, the Royal Postgraduate School of Medicine, where the academic head as in the United States is also chief of service, a hospital which has earned international recognition for the quality and quantity of its clinical research.

I am convinced that if academic surgery is to advance our academic heads must be given the authority they require to effect change so that new clinical developments can be introduced, clinical research organised, and education coordinated. There must be safeguarding of the need to introduce change-for students should be educated in hospitals with the most modern facilities. Nowhere is this now needed more than in the guidance of surgical trainees, who express confusion at the various opinions of the different consultants to whom they are attached and distrust of the committees on which their further career so often now depends. The American system of residency training has much to commend it, for it is clear with whom the responsibility for training lies, to whom the resident is primarily accountable, and by whom excellence is expected.

I have indicated ways in which I believe that the British habit of evolution has acted against academic surgical progress. We are now standing, through the white paper, on the brink of a revolution in the organisation of our health service, and I would have hoped that the opportunity would be taken to have established at least one or two medical centres along true university lines. The introduction of the NHS gave an opportunity which the Goodenough committee did not take; I see little sign yet that it will be any different on this occasion despite the intent of government to protect medical education and research. The reaction of the profession is disappointing, for rather than trying to go forward with government to right some of the wrongs and produce the best possible system of health care it is letting tradition, conservation, and vested interests again hold sway-and this can only prevent progress.

1 Dickens C. A tale of two cities. London: Nelson, 1907:2.

Interdepartmental Committee on Medical Schools. Report. Ministry of Health for Scotland, HMSO, 1944. (Goodenough report.)

3 Blandy JP, Blumgart LH, Collis JL, et al. Surgical training. Lance 1975;ii:656.

4 Association of Surgeons of Great Britain and Ireland. Examinations leading to the FRCS diploma. Br $\mathcal{F}$ Surg 1989;76:1091

5 Chisolm GD, Todd I, McArthur J, Kneafsey DV. Surgical examinations. Lancet 1989; ;:1454.

6 Smith R. How fast flows the brain drain? Br Med $\mathcal{F}$ 1988;296:987-90.

7 Smith R. International comparisons of funding and output of research: bye bye Britain. BrMed f 1988;296:409-12.

8 Smith R. Medical research: everybody's doing it. $\mathrm{Br} \mathrm{Med}$ f 1988;296:116-9.

9 Smith R. The funding of medical research: going up or coming down? BrMed F 1988;296:267-70.

10 Committee on Higher Education. Report. London: HMSO, 1963. (Cmnd 2154.) (Robbins report.)

11 Royal Commission on Medical Education. Report. London: HMSO, 1965. (Cmnd 3569.) (Todd report.)

12 Medawar PB. Advice to a young scientist. New York: Harper and Row, 1979:13. 13 Platt Lord. Medical science: master or servant? Br Med $\mathcal{F} 1967$;iv:439-44.

14 Flexner A. Medical education in Europe 1912. A report to the Carnegie Foundation for the Advancement of Teaching. New York: Carnegie Foundation, 1912. 15 Osler W. The hospital unit in university work. Lancet 1911;i:211-3. 